Sains Malaysiana 49(3)(2020): 493-502

http://dx.doi.org/10.17576/jsm-2020-4903-04

\title{
Hidrogeologi dan Geokimia Air Bawah Tanah di Daerah Tampin, Negeri Sembilan, Malaysia
}

(Hydrogeology and Groundwater Geochemistry of the Tampin District, Negeri Sembilan, Malaysia)

\author{
Norhayati Mohd Rawi, Nursabrina Syahirah Hairudin, Norbert SimON*, LeE Khai ERn \& NorSyafina \\ ROSLAN
}

ABSTRAK

Penilaian air bawah tanah untuk kegunaan domestik adalah sangat penting untuk mengelakkan isu kesihatan kepada pengguna yang bergantung kepada air bawah tanah sebagai bekalan utama semasa krisis air dan kemarau. Lazimnya, penilaian kualiti air bawah tanah hanya dijalankan untuk menentukan keselamatan penggunaannya dan sumber semula jadi bahan pencemar sering tidak dilaporkan. Oleh itu, tujuan utama kajian ini adalah untuk menentukan kualiti air bawah tanah dan juga mengenal pasti potensi bahan pencemar dan sumbernya menggunakan kaedah Piper dan Gibbs sebagai tambahan kepada penilaian kualiti air. Analisis ini telah dijalankan ke atas 38 telaga tiub di Daerah Tampin. Daerah ini telah mengalami krisis air pada tahun 2015 semasa air di Empangan Gemencheh turun ke paras kritikal akibat daripada fenomena El Nino. Untuk tujuan analisis, data geokimia dari tahun 2013 ke 2015 telah digunakan. Berdasarkan Rajah Piper, unsur yang dominan dalam telaga tiub tersebut adalah $\mathrm{Ca}^{2+} \mathrm{HO}_{3}^{-}$, diikuti oleh $\mathrm{Na}^{+} \mathrm{HO}_{3}^{-}$, dan $\mathrm{Ca}^{2+} \mathrm{Na}^{+} \mathrm{HO}_{3}$. Evolusi hidrokimia pula adalah akibat daripada interaksi antara batuan dan pemendakan air bawah tanah berdasarkan Rajah Gibbs. Berkenaan dengan kualiti air, paras Fe didapati meningkat dalam 3 telaga tiub (NTPPW 18, RTG 27 \& RTG 53) sepanjang tahun tersebut, manakala unsur lain didapati berada pada tahap yang boleh diterima. Keputusan kajian menunjukkan bahan pencemar terbentuk daripada interaksi air dengan batuan yang terluluhawa dan juga daripada air hujan yang boleh melarutkan serta mengalirkan ion unsur logam ke dalam telaga tiub sekitar Daerah Tampin.

Kata kunci: Air bawah tanah; fiziko-kimia; Rajah Gibbs; Rajah Piper

\section{ABSTRACT}

Groundwater assessment for domestic use is vitally important to prevent health issues to users who are depending on groundwater as their main supplies especially during water crisis and drought. Often, quality of groundwater is assessed only on their safety for use, the source of natural pollutants especially from geological materials is often not reported. Therefore, the main aim of this study was to determine the water quality of tubewells and also to identify potential pollutants and their sources using Piper and Gibbs methods as an addition for water quality assessment. The Piper diagram is used to provide an understanding on the geochemical evolution of the groundwater and the Gibbs diagram shows the relationship of the water composition and the aquifer. The analysis was conducted on 38 tubewells in the District of Tampin. This district has experience water crisis in 2015 when the water in the Gemencheh Dam dropped to a critical level due to the El Nino phenomenon. For the analysis purpose, geochemical data from 2013 to 2015 from 8 active tubewells were used. Based on the Piper Diagram, the dominant element found in wells are $\mathrm{Ca}^{2+} \mathrm{HO}_{3}^{-}$, followed by $\mathrm{Na}^{+} \mathrm{HO}_{3}^{-}$and $\mathrm{Ca}^{-} \mathrm{Na}_{-}^{-} \mathrm{HO}_{3}^{-}$. The hydro-chemical evolution is mainly due to the interaction between rocks and precipitation of groundwater based on the Gibbs Diagram. On the water quality, the level of Fe is found to be increasing in 3 wells (NTPPW 18, RTG 27 \& RTG 53) over the years, while other critical elements remain to be in acceptable level. The overall finding shows that pollutants may enter the wells from weathered rock and also from rainfall that will saturate as well as draining heavy metal ions into wells around the Tampin District.

Keywords: Gibbs Diagram; physico-chemical; Piper Diagram; underground water

\section{Pengenalan}

Air bawah tanah adalah merupakan salah satu daripada keperluan asas penduduk di muka bumi. Ia juga merupakan sumber alam yang boleh diperbaharui dan menjadi alternatif kepada sumber minuman bagi kelangsungan hidup (Hamzah et al. 2014). Semakin hari permintaan kepada air bawah tanah semakin bertambah, ini disebabkan oleh berlakunya pertambahan penduduk dan kesedaran terhadap kepentingan air bawah tanah. Tidak dinafikan juga bahawa air bawah tanah ini adalah sumber air bersih (tawar) dan diambil dengan jumlah yang paling besar di dunia (Taniguchi \& Holman 2010).

Air bawah tanah ini disimpan di bawah permukaan tanah serta terletak pada ruang pori antara butiran, retakan 
atau pada zon pelarutan. Disebabkan peningkatan permintaan untuk air bawah tanah ini, maka kualiti air bawah tanah adalah merupakan perkara utama yang harus diketahui. Ini adalah bagi mengelakkan berlakunya pencemaran tanah dan air bawah tanah hasil daripada aktiviti yang dilakukan oleh penduduk bandar, industri dan aktiviti pertanian (Shirazi et al. 2015). Kajian berkaitan kualiti air bawah tanah pada peringkat global telah dijalankan oleh ramai pengkaji, antaranya adalah Annapoorna dan Janardhana (2015), Batayneh dan Zumlot (2012), Kumar et al. (2014), Seribu dan Jakarta (2017), Shankar et al. (2017) dan Subyani dan Ahmadi (2010). Manakala di Malaysia pula, kajian tentang kualiti air bawah tanah telah dijalankan di Negeri Melaka (Shirazi et al. 2015), Pulau Manukan (Umar Kura et al. 2013), Kelantan (Hamzah et al. 2014), Terengganu (Umar Kura et al. 2013) dan di kawasan Pantai Barat Semenanjung Malaysia (Sapari et al. 2011).

Untuk kajian ini, Daerah Tampin telah dipilih sebagai lokasi kajian kerana ia adalah merupakan kawasan yang sedang membangun dan sangat memerlukan bekalan air bersih. Ini turut disokong dengan pertambahan penduduk, kerancakan aktiviti perindustrian dan pertanian. Selain daripada itu, fenomena El Nino yang telah melanda Daerah Tampin pada awal tahun 2015 telah menyebabkan kawasan ini mengalami kekurangan air disebabkan oleh penyusutan paras air di Empangan Gemencheh (Bernama 2018; Utusan 2016). Pengepaman air bawah tanah yang tidak terkawal bagi menampung keperluan penduduk boleh mengakibatkan berlakunya pencemaran air bawah tanah. Oleh yang demikian, kajian ini dilakukan untuk melihat dan mengetahui jenis asalan air bawah tanah dan tahap kualiti air bawah tanah di Daerah Tampin bagi kegunaan awam.

Pengenalpastian sifat air bawah tanah ini dikaji dengan menggunakan kajian hidrokimia. Kajian ini dapat mengenal pasti jenis air bawah tanah dan hubungannya dengan geologi serta persekitaran yang mempengaruhi kompisisi dan kualiti air bawah tanah tersebut. Hem (1985) telah menyatakan bahawa analisis hidrogeokimia dapat digunakan bagi menganalisis proses yang berlaku kepada air bawah tanah, menganalisis jenis batuan yang dominan serta yang mempengaruhi kualiti air bawah tanah. Ia juga bertujuan untuk menilai kualiti air bawah tanah berdasarkan kepada parameter fizikal dan kimia dan dapat menentukan kesesuaiannya dalam kehidupan harian. Kefahaman tentang interaksi antara air dan batuan di dalam aliran air bawah tanah dan proses luluhawa telah dikaji dengan menggunakan proses kimia dan diadaptasi daripada persamaan tindak balas kimia antara ion seperti kalsium, magnesium, sodium, kalium, klorida dan sulfat. Rajah Piper telah digunakan untuk ujian ini, manakala Rajah Gibbs pula telah digunakan untuk mengenal pasti evolusi geokimia air bawah tanah (Hwang et al. 2016).

\section{KAWASAN KAJIAN}

Daerah Tampin merupakan sebuah daerah yang terletak di selatan Negeri Sembilan dan bersempadan dengan negeri
Melaka dan Pahang. Ia merupakan salah satu daripada tujuh daerah yang terletak di Negeri Sembilan. Berkeluasan $878.7 \mathrm{~km}^{2}$ dan dibahagikan kepada 4 mukim iaitu Pekan Tampin, Air Kuning, Gemencheh dan Gemas.

Lokasi daerah ini terletak di garis longitud $102^{\circ} 0{ }^{\prime} \mathrm{E}$ hingga $102^{\circ} 0{ }^{\prime} \mathrm{E}$ dan garis latitud $2^{\circ} 05^{\prime} \mathrm{N}$ hingga $2^{\circ} 42^{\prime} \mathrm{N}$ (Rajah 1). Kawasan kajian ini secara keseluruhannya terdiri daripada kawasan pertanian yang terdiri daripada getah, kelapa sawit, sayur-sayuran, ternakan haiwan dan kebun buah-buahan. Namun begitu, kawasan yang sedang dibangunkan semakin bertambah berikutan pembangunan yang berlaku di daerah ini.

Menurut kajian yang telah dijalankan oleh Syarikat Pengurusan Air Negara (SPAN 2014), secara keseluruhannya penduduk di daerah Tampin menggunakan air sebanyak 250 liter setiap orang pada setiap hari. Populasi penduduk di daerah Tampin adalah seramai 90,200 orang dan dianggarkan akan bertambah setiap tahun. Menurut Unit Perancang Ekonomi Negeri Sembilan berdasarkan kepada data sosioekonomi yang disediakan pada tahun 2015 (UPEN 2015), didapati bahawa jumlah penduduk di daerah Tampin telah bertambah daripada 87,600 orang pada tahun 2012 menjadi 90,200 orang pada tahun 2015. Ini menunjukkan bahawa jumlah penduduk di daerah Tampin bertambah sebanyak 3\% dalam tempoh 3 tahun dan pertambahan ini akan terus berlaku saban tahun. Antara sektor pekerjaan utama penduduk di kawasan ini adalah pertanian, perniagaan dan bekerja di dalam sektor kerajaan dan swasta.

Secara umumnya, daerah Tampin didasari oleh tiga formasi batuan iaitu Syis Pilah, Formasi Kepis dan Formasi Gemas (Rajah 1), manakala jasad batuan granit terdiri daripada Pluton Batang Melaka yang terdapat di bahagian barat kawasan kajian. Formasi Gemas atau lebih dikenali sebagai Formasi Semantan adalah formasi yang berusia Trias Tengah hingga Akhir (Khoo 1998). Antara batuan yang terdapat di dalam formasi ini adalah syal, selang lapis antara tuf dan batu pasir, syal bertuf dan batu pasir bertuf. Turut terdapat di dalam formasi ini adalah konglomerat, marmar, filit, hornfels, argilit dan syal berkarbon. Kawasan Gemencheh pula didasari oleh batuan syal, filit, sabak, batu pasir dan syis.

\section{BAHAN DAN KAEDAH KAJIAN}

Secara keseluruhannya, sebanyak 38 buah telaga telah dikenal pasti dan terdiri daripada pelbagai jenis batuan dan mempunyai kedalamanan antara 30-85 m. Sebanyak tiga kaedah kajian telah dijalankan iaitu inventori lapangan yang meliputi persampelan air bawah tanah yang melibatkan cerapan paras air bawah tanah, maklumat konduktiviti $(\mu \mathrm{S} / \mathrm{cm})$, suhu air bawah tanah $\left({ }^{\circ} \mathrm{C}\right)$, keasidan (nilai $\mathrm{pH}$ ) air bawah tanah dan Jumlah Pepejal Terlarut (TDS). Bagi mengetahui jenis tindak balas kimia yang berlaku antara air bawah tanah dan batuan induk yang membawa kepada jenis air tanah di kawasan ini pula, analisis data dengan menggunakan Rajah Piper dan Rajah Gibbs telah digunakan dengan mengguna pakai data sedia 


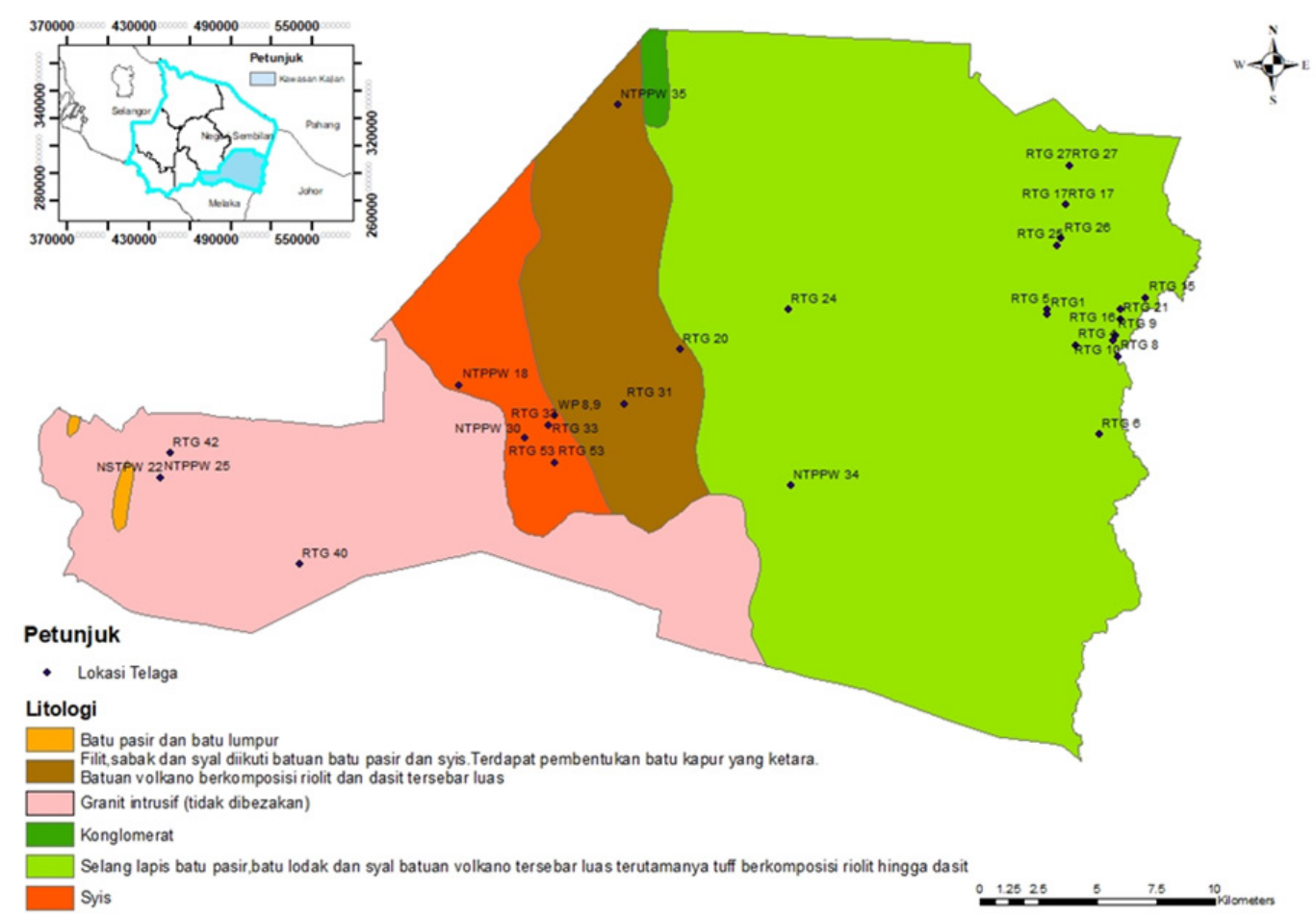

RAJAH 1. Peta menunjukkan lokasi kawasan kajian bersama maklumat geologi kawasan Tampin (Sumber: Diubah suai daripada Jabatan Mineral dan Geosains 2012)

ada. Tahap kualiti air bawah tanah juga dinilai dengan melakukan analisis makmal. Tujuan analisis ini adalah bagi mengetahui tahap pencemaran air bawah tanah dan dibandingkan dengan piawai yang telah ditetapkan oleh Kementerian Kesihatan Malaysia.

\section{KERJA LAPANGAN}

Kerja lapangan telah dijalankan pada 11 Mac 2016 yang melibatkan kawasan Madrasah Repah, Kg Ulu Ladang, Kg Londah, Kg Tenusu dan Masjid Jamek Gemencheh di Daerah Tampin. Cerapan terhadap sampel air bawah tanah daripada telaga pemantauan telah dilakukan dengan menggunakan alat pengukur iaitu YSI Multi Probe System 556 MPS. Antara cerapan yang dilakukan adalah cerapan paras air bawah tanah, maklumat konduktiviti $(\mu \mathrm{S} / \mathrm{cm})$, suhu air bawah tanah $\left({ }^{\circ} \mathrm{C}\right)$, keasidan (nilai $\mathrm{pH}$ ) air bawah tanah dan Jumlah Pepejal Terlarut (TDS).

\section{PERSAMPELAN AIR TANAH}

Persampelan air bawah tanah dibuat untuk penentuan parameter kimia yang akan dijalankan di makmal. Sampel air bawah tanah diisi ke dalam botol sampel plastik polietilena (HDPE) sebanyak 1 dan 2 liter sehingga penuh. Sebanyak $10 \mathrm{~mL}$ asid nitrik, $\mathrm{HNO}_{3}(\mathrm{pH}<2)$ dengan kepekatan 50\% ditambah ke dalam botol sampel 1 liter untuk pengawetan sampel. Tujuan pengawetan adalah untuk mengekalkan keadaan sebenar sampel air bawah tanah dengan cara menstabilkan parameter yang dikehendaki sebelum dihantar ke makmal untuk diuji.
Seterusnya, sampel air ini diuji kepekatan logam berat terlarut di dalam air bawah tanah dengan menggunakan analisis Inductively Coupled Plasma Mass Spectrometry (ICP-MS). Penentuan kualiti air bawah tanah dijalankan dengan menggunakan data yang dikumpul dari tahun 2013 ke 2015 untuk 8 telaga yang masih aktif (Jadual 3).

\section{KAJIAN ANALISIS DATA}

Analisis kualiti air dilakukan dengan menggunakan analisis Ujian Piper dan Ujian Gibbs. Ujian ini dijalankan dengan menggunakan maklumat air bawah tanah daripada telaga pemantauan dan analisis data daripada telaga sedia ada. Rekod data telaga diperoleh daripada data telaga tahun 1988 hingga 2015. Kesemua telaga adalah telaga yang dibina oleh Jabatan Mineral dan Geosains. Sebanyak 38 telaga tiub telah dikenal pasti dan direkodkan. Maklumat yang digunakan di dalam ujian ini adalah maklumat Jumlah Pepejal Terlarut (TDS), nilai pH, maklumat Kumpulan Anion yang terdiri daripada kalium $\left(\mathrm{K}^{+}\right)$, natrium $\left(\mathrm{Na}^{+}\right)$, magnesium $\left(\mathrm{Mg}^{2+}\right)$, kalsium $\left(\mathrm{Ca}^{2+}\right)$ dan analisis kumpulan kation yang terdiri daripada bikarbonat $\left(\mathrm{HCO}_{3}{ }^{-}\right)$, klorida $\left(\mathrm{Cl}^{-}\right)$, sulfat $\left(\mathrm{SO}_{4}{ }^{2-}\right)$ dan karbonat $\left(\mathrm{CO}_{3}\right.$. Penentuan asalan sumber air bawah tanah ini telah dianalisis dengan menggunakan Gambarajah Piper (Piper 1944) seperti yang ditunjukkan pada Rajah 2. Gambarajah Piper ini adalah ujian yang biasanya dilakukan bagi mengetahui maklumat hidrokimia di dalam sesuatu akuifer (Niaz et al. 2003).

Gambarajah Gibbs digunakan untuk menafsir kesan hasil proses hidrokimia seperti pemendakan, interaksi antara air dan batuan serta penyejatan pada geokimia air 


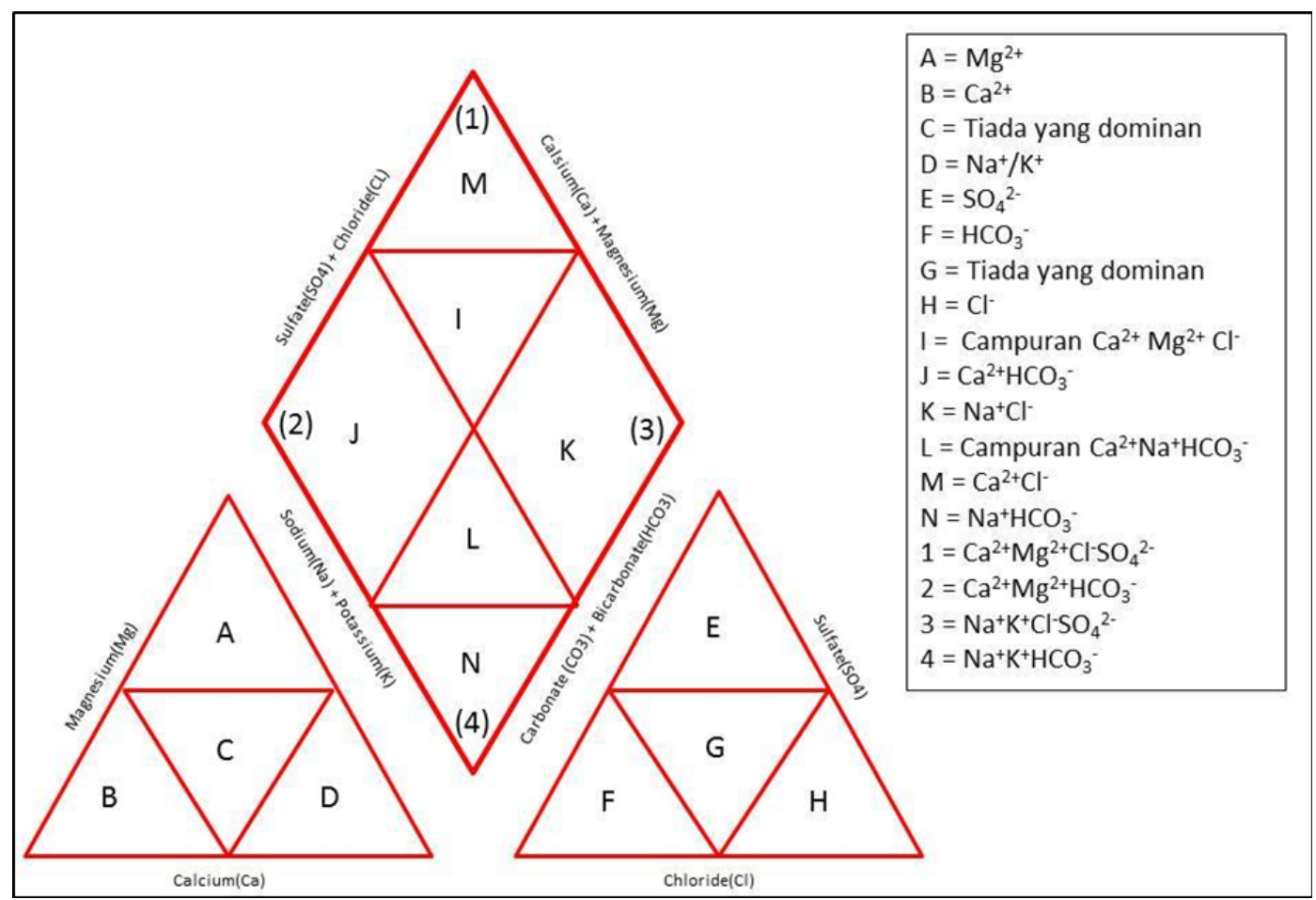

RAJAH 2. Rajah Piper yang digunakan dalam analisis kualiti air bawah tanah (Sumber: Diubah suai daripada Piper 1994)

bawah tanah. Hasil tindak balas antara air bawah tanah dan bahan mineral ini dapat membuktikan bahawa asalan air mempunyai hubungan yang penting dalam ujian kualiti air bawah tanah. Bagi ujian ini, analisis Nisbah Gibbs (Gibbs 1970) dilakukan dengan persamaan berikut:

Persamaan Gibbs (anion) $=\left(\mathrm{Cl}^{-}\right) /\left(\mathrm{Cl}^{-}+\mathrm{HCO}_{3}^{-}\right)$

Persamaan Gibbs (kation) $=\left(\mathrm{Na}^{+}+\mathrm{K}^{+}\right) /\left(\mathrm{Na}^{+}+\mathrm{K}^{+}+\mathrm{Ca}^{2+}\right)$

\section{KEPUTUSAN DAN PERBINCANGAN}

\section{SUHU AIR BAWAH TANAH DI KAWASAN KAJIAN}

Suhu adalah parameter penting kerana ia berfungsi untuk meningkatkan tindak balas fizikal dan kimia di dalam air. Perubahan suhu boleh menyebabkan perubahan pada oksigen terlarut, pengurangan suhu menyebabkan bilangan oksigen terlarut meningkat dan perkara yang sebaliknya berlaku sekiranya suhu berkurangan (Hosseini et al. 2017). Peningkatan suhu akan menyebabkan pengurangan gas terlarut seperti $\mathrm{O}_{2}, \mathrm{CO}_{2}, \mathrm{~N}_{2}$ and $\mathrm{CH}_{4}$. Ia juga akan menyebabkan pertumbuhan mikroorganisma dengan meningkatkan rasa, bau, warna dan menyebabkan berlakunya masalah hakisan. Adalah diketahui juga bahawa kualiti air bawah tanah dipengaruhi oleh persekitarannya. Berdasarkan kepada analisis fizikal yang telah dilakukan di lapangan, didapati bahawa semua sampel air bawah tanah ini adalah jernih (tidak keruh) dan suhu air bawah tanah ketika sampel diambil adalah antara $30.5^{\circ} \mathrm{C}$ hingga $33.1^{\circ} \mathrm{C}$ dengan purata bacaannya adalah $31.8^{\circ} \mathrm{C}$.

\section{KONDUKTIVITI}

Konduktiviti adalah merupakan parameter pengukuran bahan bukan organik terlarut yang terion dan membentuk elektrolit. Ia secara langsung berkaitan dengan kepekatan ion dalam air serta memberi petunjuk tentang jumlah penggantian ion yang terlarut dalam air disebabkan oleh pengaliran elektrik. Ion konduktif ini berasal daripada garam terlarut dan bahan bukan organik seperti alkali, klorida, sulfida dan sebatian karbonat (Hakim et al. 2009). Julat konduktiviti air adalah antara $10 \mu \mathrm{S} / \mathrm{cm}$ dan 1000 $\mu \mathrm{S} / \mathrm{cm}$, namun sekiranya air sesebuah kawasan tercemar, bacaan konduktiviti boleh melebihi julat tersebut (Chapman 1992). Hasil daripada nilai yang telah diperoleh, didapati bahawa nilai konduktiviti air di Daerah Tampin adalah antara $92.8 \mathrm{mS} / \mathrm{cm}$ dan $308 \mathrm{mS} / \mathrm{cm}$ dan ini membuktikan bahawa air bawah tanah di kawasan Tampin masih belum tercemar.

\section{JUMLAH PEPEJAL TERLARUT (TDS)}

Jumlah Pepejal Terlarut (TDS) ditentukan dengan pengukuran semua garam dalam larutan (Balachandar et al. 2010). Berdasarkan kepada maklumat Jumlah Pepejal Terlarut (TDS) yang telah diperoleh dalam air telaga, didapati bahawa $18 \%$ daripada sampel air bawah tanah ini terdiri daripada air bawah tanah yang peratus TDS adalah kurang daripada $100 \mathrm{mg} / \mathrm{L}, 79 \%$ adalah antara $100-500$ $\mathrm{mg} / \mathrm{L}$ dan 3\% adalah lebih daripada $500 \mathrm{mg} / \mathrm{L}$. Menurut 
Davis dan De Wiest (1996), sampel air yang mempunyai nilai TDS kurang daripada $100 \mathrm{mg} / \mathrm{L}$ merupakan air tapisan, manakala $100 \mathrm{mg} / \mathrm{L}$ hingga $500 \mathrm{mg} / \mathrm{L}$ adalah air minuman dan selebihnya adalah sesuai untuk minuman. Tetapi ia akan menjadi tidak sesuai untuk diminum sekiranya nilai TDS adalah melebihi $1,000 \mathrm{mg} / \mathrm{L}$. Oleh yang demikian, didapati bahawa kawasan Tampin mempunyai air bawah tanah yang terdiri daripada air yang sesuai untuk kegunaan domestik, pertanian dan industri. Jadual 1 menunjukkan kepekatan ion dan pepejal terlarut yang diperoleh hasil daripada analisis hidrokimia sampelsampel air bawah tanah.

\section{NILAI $\mathrm{pH}$}

Nilai pH larutan ialah ukuran ion hidrogen yang hadir di dalam sesuatu sampel air bawah tanah yang dianalisis. Kehadiran ion hidrogen yang banyak menjadikan larutan berasid, sementara kekurangan ion $\mathrm{H}$ menjadikannya beralkali. Larutan beralkali mempunyai banyak ion hidroksida, $\mathrm{OH}$. Kualiti air bawah tanah juga sangat dipengaruhi oleh persekitarannya. Secara umumnya, berdasarkan kepada analisis fizikal yang telah dijalankan di kawasan ini, didapati nilai $\mathrm{pH}$ bagi kawasan Tampin berjulat $6-8$.1. Ini menunjukkan bahawa air bawah tanah di kawasan kajian adalah terdiri daripada air berasid hingga beralkali. Nilai $\mathrm{pH}$ yang telah ditetapkan oleh Pertubuhan Kesihatan Sedunia (WHO 1996) adalah antara 6.5 - 9.2 manakala julat nilai piawai yang telah ditetapkan oleh Kementerian Kesihatan Malaysia (KKM 2004) pula adalah antara 6.41 hingga 7.65 (Nilai yang ditetapkan oleh KKM adalah 5.5 hingga 9 bagi air mentah dan 6.5 hingga 9 bagi air minuman). Namun begitu, daripada sejumlah sampel air bawah tanah yang telah diperoleh, 4 daripadanya kurang daripada nilai yang telah ditetapkan. Telaga tersebut adalah RTG 63, NTPPW 18, RTG 60 dan WP 8. Pengurangan nilai $\mathrm{pH}$ ini mungkin disebabkan oleh luluhawa batuan volkanik yang terdapat di kawasan kajian. Ia juga terjadi akibat proses perluluhawa batuan yang bersifat asid seperti granit secara semula jadi. Apabila batuan ini terluluhawa di bawah permukaan, peresapan larutan yang bersifat asid akan meresap dalam air bawah tanah. Penambahan komposisi asid ini akan mengurangkan nilai $\mathrm{pH}$ air. Interaksi antara permukaan air bawah tanah (khususnya bagi telaga yang terdedah) dengan gas karbon dioksida daripada udara yang meresap ke dalam air bawah tanah turut menyumbang kepada perubahan nilai pH ini (Hamzah et al. 2014). Maklumat lengkap nilai pH, TDS dan unsurunsur yang hadir di dalam sampel air bawah tanah ini adalah seperti dalam Jadual 2.

Berdasarkan analisis Gambarajah Piper (Rajah 3), didapati bahawa sampel air bawah tanah di kawasan Tampin adalah dominan dengan jenis air $\mathrm{Ca}^{2+} \mathrm{HCO}_{3}$ yang mana sumber air bawah tanah ini adalah daripada kawasan cetek dan adalah merupakan air bawah tanah semula jadi hasil daripada serapan air dari permukaan tanah.

Secara purata, nilai bacaan bagi setiap kation adalah $\mathrm{K}^{+}(1.24 \mathrm{mg} / \mathrm{L}), \mathrm{Na}^{+}(11.40 \mathrm{mg} / \mathrm{L}), \mathrm{Mg}^{2+}(4.16 \mathrm{mg} / \mathrm{L})$ dan $\mathrm{Ca}^{2+}(41.60 \mathrm{mg} / \mathrm{L})$. Pada Gambarajah Piper, segitiga kation menunjukkan bahawa kandungan ion pada kation adalah bertumpu pada bahagian kiri kation. Ini menunjukkan bahawa kation adalah dominan pada kalsium dan mengalami pengurangan pada natrium, namun masih terdapat sedikit ion magnesium. Bagi anion pula, nilai purata bacaan bagi setiap anion adalah $\mathrm{HCO}_{3}^{-}(145.06$ $\mathrm{mg} / \mathrm{L}), \mathrm{Cl}^{-}(4.26 \mathrm{mg} / \mathrm{L}), \mathrm{SO}_{4}{ }^{2-}(8.8 \mathrm{mg} / \mathrm{L})$ dan $(4.90 \mathrm{mg} / \mathrm{L})$. Berdasarkan Gambarajah Piper, didapati bahawa penumpuan adalah pada sebelah kiri segitiga dan sedikit di bahagian bawah kuadran. Ini menunjukkan bahawa kawasan ini adalah dominan pada bikarbonat (asalan air bawah tanah cetek) dan kalsium (asalan air bawah tanah hasil peresapan ion) dan mengalami pengurangan pada ion karbonat. Hal ini menunjukkan bahawa kandungan kalsium dan bikarbonat adalah amat tinggi di kawasan Tampin. Ion kalsium ini adalah kebiasaannya berasosiasi dengan mineral karbonat seperti kalsit $\left(\mathrm{CaCO}_{3}\right)$ dan dolomite $(\mathrm{CaMg})\left(\mathrm{CaCO}_{3}\right)_{2}$ yang wujud sebagai mineral sekunder batuan granit (Hamzah et al. 2014).

Gambarajah Gibbs digunakan secara meluas untuk menunjukkan hubungan antara komposisi air dan ciri litologi aquifer. Tiga ruang yang berbeza telah ditetapkan dalam Rajah Gibbs yang terdiri daripada kawasan yang Dominasi Air Hujan (Precipitation Dominance), Dominasi Penyejatan (Evaporation Dominance) dan Dominasi Batuan (Rock Dominance) (Gibbs 1970). Nisbah yang digunapakai adalah $\mathrm{Cl} /\left(\mathrm{Cl}+\mathrm{HCO}_{3}\right)$ dan $\mathrm{Na} / \mathrm{Na}+\mathrm{Ca}^{2+}$ melawan Jumlah Pepejal Terlarut (mg/L).

Berdasarkan keputusan yang ditunjukkan dalam Rajah 4, didapati bahawa air bawah tanah di daerah Tampin dipengaruhi oleh komposisi batuan sebagai kawalan anion $\left(\mathrm{Cl} /\left(\mathrm{Cl}+\mathrm{HCO}_{3}\right)\right.$ dan kation $\left(\mathrm{Na} / \mathrm{Na}^{+} \mathrm{Ca}^{2+}\right)$ yang utama. Ini menunjukkan bahawa telah berlaku interaksi antara bahan kimia hasil tindak balas antara batuan dan air bawah permukaan bumi dan ia adalah lebih dominan daripada air

JADUAL 1. Rajah menunjukkan kategori telaga berdasarkan kepada Jumlah Pepejal Terlarut (TDS)(mg/L)

\begin{tabular}{cl}
\hline Nilai Jumlah Pepejal Terlarut (TDS), mg/L & \multicolumn{1}{c}{ No Telaga } \\
\hline$<100$ & WP 8, RTG 63, RTG 33, NTPPW 18, RTG 60, NTPPW 22, RTG 53 \\
$100-500$ & WP 1, RTG 15, RTG 40, RTG 58, RTG 20, RTG 42, RTG 24, RTG 17, TW 1, \\
& NTPPW 34, RTG1, RTG 41, NTPPW 25, RTG 8, RTG 4, RTG 16, RTG 27, RTG \\
& 5,RTG 21, RTG 31, RTG 27, RTG 17, RTG 9, RTG 53, RTG 33, RTG 26, RTG 23, \\
& RTG 6, RTG 10, NTPPW 30, RTG 25 \\
& NTPPW 35 \\
\hline
\end{tabular}


JADUAL 2. Jadual menunjukkan nilai unsur yang hadir di dalam sampel air bawah tanah Daerah Tampin

\begin{tabular}{|c|c|c|c|c|c|c|c|c|c|c|}
\hline No Telaga & TDS & $\mathrm{K}^{+}$ & $\mathrm{Na}^{+}$ & $\mathrm{Mg}^{2+}$ & $\mathrm{Ca}^{2+}$ & $\mathrm{HCO}_{3}^{-}$ & $\mathrm{Cl}^{-}$ & $\mathrm{SO}_{4}{ }^{2^{-}}$ & $\mathrm{CO} 3$ & $\mathrm{pH}$ \\
\hline Piawaian $\mathrm{MOH}$ & 1,000 & - & 200 & 150 & - & - & 250 & 250 & - & $6.5-8.5$ \\
\hline RTG 17 & 176 & 1 & 18 & 4 & 26 & 107 & $<1$ & 1.6 & 7 & 7.5 \\
\hline RTG 27 & 230 & 2.5 & 19 & 3.4 & 44 & 107 & 2 & 5.08 & 19 & 7.3 \\
\hline NTPPW 18 & 56 & 1.9 & 4 & $<0.5$ & 3 & 14 & 4 & 11.8 & 1 & 6 \\
\hline NTPPW 22 & 98 & 1.8 & 9 & 0.9 & 7.6 & 45 & 2 & 9.94 & 1 & 7 \\
\hline RTG 53 & 98 & 1.5 & 6.6 & 1.4 & 23 & 50 & 8 & 8.45 & 5 & 7 \\
\hline RTG 33 & 36 & 2.8 & 7.4 & 0.6 & 3.5 & 21 & 8 & 1.24 & 1 & 7.2 \\
\hline NTPPW 34 & 197 & 0 & 0 & 10.7 & 22.1 & 0 & 3.5 & 0.8 & 0 & 6.5 \\
\hline NTPPW 25 & 210 & 0.7 & 6.8 & 2.6 & 64 & 188 & 6.1 & 30 & 0 & 8 \\
\hline NTPPW 30 & 297 & 0 & 0 & 6.38 & 20.8 & 0 & 6.2 & 1.5 & 0 & 6.5 \\
\hline WP 1 & 126 & 0 & 0 & 8.09 & 12.5 & 0 & 7.6 & 2.3 & 0 & 6.6 \\
\hline WP 8 & 14 & 0 & 0 & 2.73 & 20.4 & 0 & 7.8 & 3.1 & 0 & 6.2 \\
\hline NTPPW 35 & 658 & 0 & 0 & 2.61 & 37.5 & 0 & 1.9 & 3.7 & 0 & 7.3 \\
\hline RTG1 & 204 & 0.7 & 10 & 6 & 38 & 161 & 4 & 11 & 1.2 & 7 \\
\hline RTG 4 & 216 & 2 & 12 & 3 & 30 & 129 & 3 & 9 & 10 & 7.5 \\
\hline RTG 5 & 232 & 1 & 18 & 3 & 42 & 190 & 3 & 9 & 1.2 & 8 \\
\hline RTG 6 & 292 & 0.71 & 40 & 7 & 35 & 231 & 3 & 9 & 13 & 8.1 \\
\hline RTG 8 & 212 & 0.7 & 20 & 3 & 44 & 177 & 3 & 9 & 11 & 8 \\
\hline RTG 9 & 246 & 0.7 & 5 & 5 & 90 & 259 & 5 & 11 & 12 & 7.6 \\
\hline RTG 10 & 296 & 0.5 & 5 & 5 & 63 & 181 & 3 & 9 & 12 & 7.6 \\
\hline RTG 15 & 128 & 0.8 & 8.2 & 1.6 & 19.4 & 85.9 & 4.6 & 9 & 1.2 & 6.8 \\
\hline RTG 16 & 228 & 1 & 20.7 & 3.5 & 82 & 289.1 & 16 & 9 & 13.2 & 7.7 \\
\hline RTG 17 & 244 & 1 & 14 & 5.4 & 61.1 & 207.4 & 4 & 9 & 14.4 & 6.5 \\
\hline RTG 20 & 166 & 0.7 & 4.2 & 6.2 & 93.7 & 304.8 & 4 & 9 & 11.5 & 7.5 \\
\hline RTG 21 & 232 & 0.8 & 35.8 & 3.5 & 38.5 & 194.5 & 2 & 9 & 16.8 & 7.8 \\
\hline RTG 23 & 280 & 1.5 & 18.6 & 4.2 & 54.1 & 242.8 & 2 & 9 & 1.2 & 7.3 \\
\hline RTG 24 & 172 & 0.3 & 15.9 & 10.1 & 22.7 & 148.4 & 3 & 14 & 1.2 & 7.4 \\
\hline RTG 25 & 300 & 1.4 & 5.3 & 4 & 92.3 & 317.2 & 2 & 9 & 1.2 & 7.3 \\
\hline RTG 26 & 266 & 0.8 & 3.6 & 4.3 & 88.8 & 245.2 & 3 & 16.5 & 19.2 & 7.7 \\
\hline RTG 27 & 242 & 3 & 19 & 3.4 & 48.2 & 212.3 & 3 & 10 & 1.2 & 7.9 \\
\hline RTG 31 & 238 & 1 & 9.8 & 3.3 & 64.5 & 223.3 & 6 & 13 & 8.4 & 7.9 \\
\hline RTG 33 & 262 & 0.7 & 10.9 & 3.4 & 74.7 & 274.5 & 5 & 10 & 1.2 & 7.4 \\
\hline RTG 40 & 150 & 2.6 & 11 & 1.8 & 37.7 & 154 & 5 & 9 & 1 & 7.2 \\
\hline RTG 41 & 206 & 4.8 & 15.5 & 3.5 & 51.2 & 222 & 4 & 9 & 1 & 7.5 \\
\hline RTG 42 & 170 & 2.1 & 11.1 & 2.8 & 55.7 & 209 & 6 & 9 & 1 & 7.7 \\
\hline RTG 53 & 250 & 1.8 & 11.9 & 5.4 & 68.2 & 266.5 & 4 & 10 & 1 & 6.41 \\
\hline
\end{tabular}

hujan atau mana-mana sumber lain. Interaksi antara batuan dan air ini menunjukkan bahawa berlaku tindak balas antara komposisi bahan kimia pada litologi kawasan kajian dengan pergerakan air bawah tanah. Ini boleh ditafsirkan bahawa air bawah tanah ini didominasikan oleh interaksi antara pergerakan air bawah tanah dan bahan batuan (Shivashankara et al. 2016).

Selain daripada itu, terdapat beberapa sampel terletak di kawasan dominasi hujan. Berbanding dengan interaksi batu-air yang membawa perubahan ketara ke arah kimia air bawah tanah, jumlah sampel air yang jatuh pada dominasi hujan hanya dapat menunjukkan bahawa keseluruhan kawasan liputan di mana akuifer terletak kurang terjejas dan diisi semula semasa tempoh hujan. Interaksi antara air mengalir dan bahan akuifer juga menjadi mekanisme dominan yang mengawal kimia bawah tanah di kawasan tersebut (Liang et al. 2018).

Secara keseluruhannya, mekanisme yang memberikan perubahan dan impak yang paling ketara ke air bawah tanah di kawasan Tampin dikuasai oleh interaksi antara air 


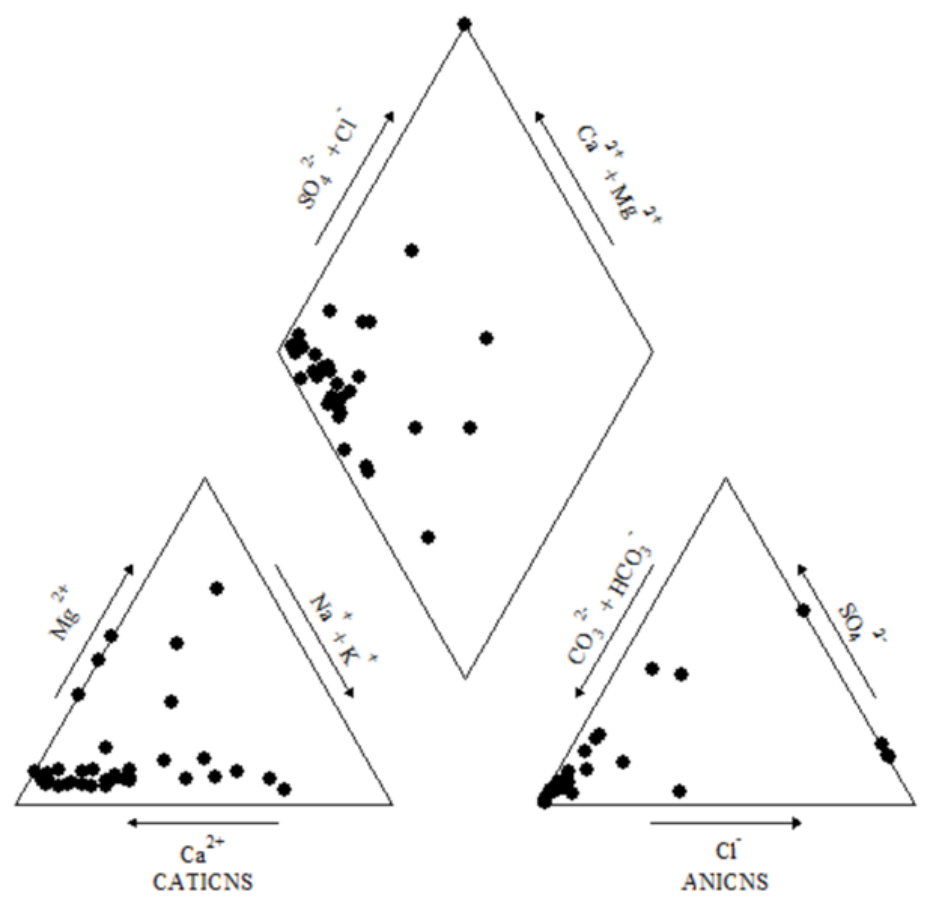

RAJAH 3. Rajah Piper hasil analisis 38 sampel air bawah tanah
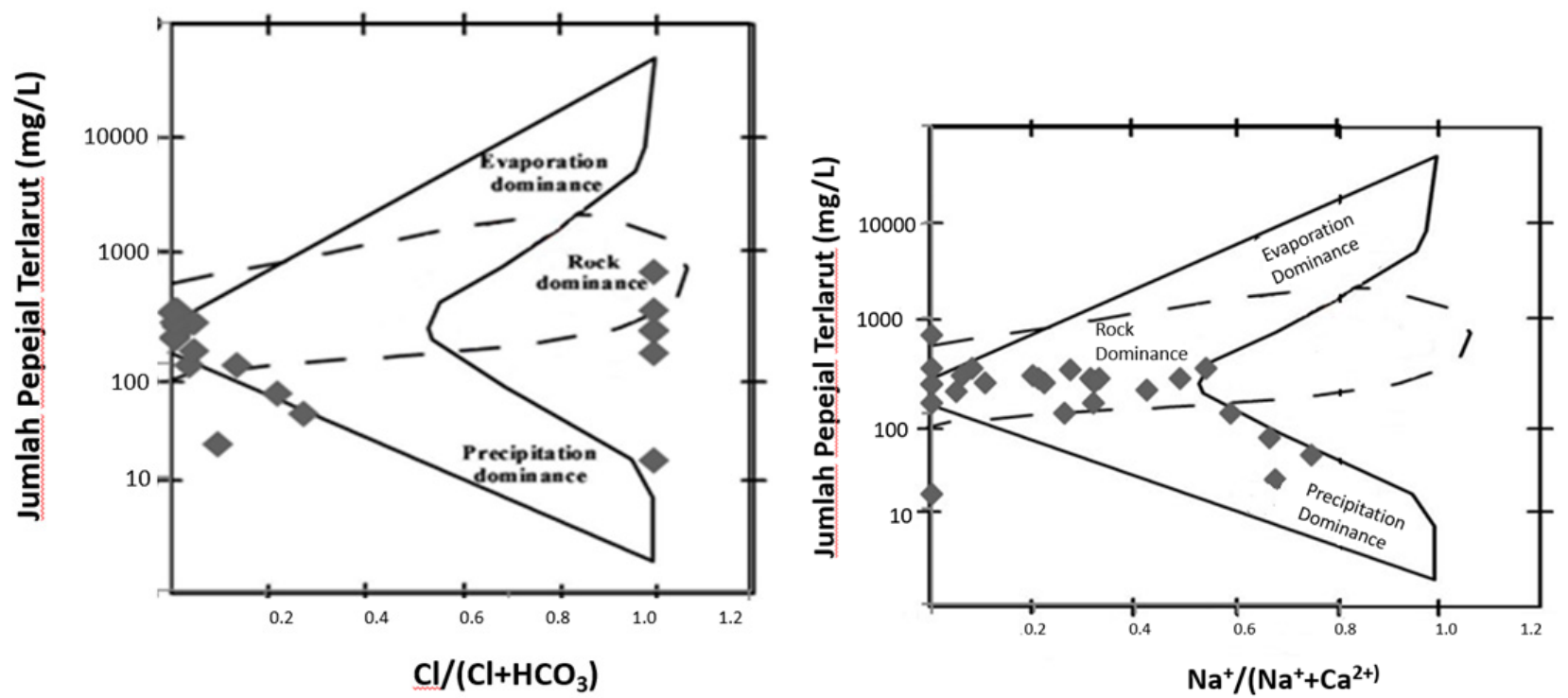

RAJAH 4. Rajah menunjukkan proses utama yang menyumbang kepada kawalan kimia air bawah tanah (Sumber: Diubah suai daripada Gibbs 1970)

dalam litiologi akuifer dan bahan-bahan yang terdiri daripada akuifer itu sendiri.

\section{KANDUNGAN LOGAM BERAT}

Kepekatan unsur-unsur logam tertentu yang rendah atau tinggi melebihi bacaan piawaiannya boleh terjadi disebabkan oleh faktor geologi semula jadi. Unsur yang hadir dalam air bawah tanah ini merupakan sebahagian daripada unsur yang melimpah dalam kerak bumi. Bagi kawasan kajian ini, batuan granit mempengaruhi kandungan kimia air tanah kerana batuan ini adalah paling dominan di kawasan kajian.

Sebanyak 8 unsur telah dikenal pasti dan dibandingkan sepanjang tiga tahun berturut-turut iaitu dari tahun 2013 hingga 2015 untuk telaga-telaga yang masih aktif sehingga kini (Jadual 3). Didapati bahawa daripada lapan unsur tersebut, lima daripadanya mempunyai nilai yang kurang daripada nilai yang telah ditetapkan oleh Kementerian Kesihatan Malaysia (2004). Namun begitu, terdapat tiga unsur logam yang melebihi nilai piawaian yang telah 
JADUAL 3. Jadual menunjukkan kandungan logam berat mengikut nombor sampel dan tahun sampel diambil

\begin{tabular}{|c|c|c|c|c|c|c|c|c|c|c|c|c|c|c|c|c|c|c|c|c|c|}
\hline \multirow{3}{*}{ Sample No / tahun } & \multirow{2}{*}{\multicolumn{3}{|c|}{$\begin{array}{c}\operatorname{As}(\mathrm{ppm}) \\
<0.01 *\end{array}$}} & \multirow{2}{*}{\multicolumn{3}{|c|}{$\begin{array}{c}\mathrm{Fe}(\mathrm{ppm}) \\
<0.3^{*}\end{array}$}} & \multirow{2}{*}{\multicolumn{3}{|c|}{$\begin{array}{c}\mathrm{Mn}(\mathrm{ppm}) \\
<0.01^{*}\end{array}$}} & \multirow{2}{*}{\multicolumn{3}{|c|}{$\begin{array}{c}\mathrm{Cu}(\mathrm{ppm}) \\
<1^{*}\end{array}$}} & \multirow{2}{*}{\multicolumn{3}{|c|}{$\begin{array}{c}\mathrm{Zn}(\mathrm{ppm}) \\
<0.05^{*}\end{array}$}} & \multirow{2}{*}{\multicolumn{3}{|c|}{$\begin{array}{c}\mathrm{Ni}(\mathrm{ppm}) \\
0.02 *\end{array}$}} & \multirow{2}{*}{\multicolumn{3}{|c|}{$\begin{array}{c}\mathrm{Cr}(\mathrm{ppm}) \\
<0.05^{*}\end{array}$}} \\
\hline & & & & & & & & & & & & & & & & & & & & & \\
\hline & 2013 & 2014 & 2015 & 2013 & 2014 & 2015 & 2013 & 2014 & 2015 & 2013 & 2014 & 2015 & 2013 & 2014 & 2015 & 2013 & 2014 & 2015 & 2013 & 2014 & 2015 \\
\hline NSTPW 23 & & & 0.01 & & & 13 & & & 0.9 & & & $<0.1$ & & & $<0.1$ & & & $<0.01$ & & & $<0.01$ \\
\hline NTPPW 18 & $<0.01$ & $<0.01$ & $<0.01$ & 0.6 & 1.2 & 2.2 & $<0.1$ & $<0.1$ & $<0.1$ & $<0.1$ & $<0.1$ & $<0.1$ & $<0.1$ & $<0.1$ & 0.2 & $<0.1$ & $<0.1$ & $<0.01$ & $<0.01$ & $<0.01$ & $<0.01$ \\
\hline NTPPW 22 & $<0.01$ & $<0.01$ & $<0.01$ & 0.3 & 0.2 & $<0.1$ & $<0.1$ & 0.2 & $<0.1$ & $<0.1$ & $<0.1$ & $<0.1$ & $<0.1$ & $<0.1$ & $<0.1$ & $<0.1$ & $<0.1$ & $<0.01$ & $<0.01$ & $<0.01$ & $<0.01$ \\
\hline RTG 02 & 0.21 & & & 37 & & & 0.8 & & & $<0.1$ & & & 1.0 & & & $<0.1$ & & & $<0.01$ & & \\
\hline RTG 17 & 0.01 & $<0.01$ & $<0.01$ & 7.6 & 2.2 & 2.8 & 0.8 & 0.6 & 0.5 & $<0.1$ & $<0.1$ & $<0.1$ & $<0.1$ & $<0.1$ & $<0.1$ & $<0.1$ & $<0.1$ & $<0.01$ & $<0.01$ & $<0.01$ & $<0.01$ \\
\hline RTG 27 & $<0.01$ & $<0.01$ & $<0.01$ & 4.1 & 6.6 & 3.8 & 0.5 & 0.3 & 0.4 & $<0.1$ & $<0.1$ & $<0.1$ & $<0.1$ & $<0.1$ & $<0.1$ & $<0.1$ & $<0.1$ & $<0.01$ & $<0.01$ & $<0.01$ & $<0.01$ \\
\hline RTG 33 & & & $<0.01$ & & & 16 & & & 0.6 & & & $<0.1$ & & & $<0.1$ & & & $<0.01$ & & & $<0.01$ \\
\hline RTG 53 & $<0.01$ & $<0.01$ & $<0.01$ & 6.3 & 2.6 & 7.4 & 0.1 & $<0.1$ & 0.3 & $<0.1$ & $<0.1$ & $<0.1$ & $<0.1$ & $<0.1$ & $<0.1$ & $<0.1$ & $<0.1$ & $<0.01$ & $<0.01$ & $<0.01$ & $<0.01$ \\
\hline
\end{tabular}

*Piawaian Kementerian Kesihatan Malaysia (Tahun 2000) 
ditetapkan. Unsur $\mathrm{As}, \mathrm{Cu}, \mathrm{Pb}, \mathrm{Ni}$ dan $\mathrm{Cu}$ menunjukkan nilaian bacaan yang sama bagi ketiga-tiga tahun. Manakala unsur $\mathrm{Fe}$ menunjukkan peningkatan bacaan pada telaga NTPPW 18, RTG 27 dan RTG 53. Unsur Mn pula menunjukkan bacaan yang hampir sama tetapi menunjukkan berlaku pengurangan bacaan pada telaga RTG17, RTG 27 dan RTG 53. Bagi bacaan unsur Zn pula, bacaannya adalah stabil bagi tiga tahun berturut-turut. Nilai bacaan yang melebihi bacaan yang telah ditetapkan pada unsur Fe dan Mn tidak menimbulkan risiko kesihatan tetapi menyebabkan kualiti air bawah tanah berkurangan disebabkan rasa, bau dan warnanya yang telah terjejas. Peningkatan bacaan $\mathrm{Fe}$ dan $\mathrm{Mn}$ ini telah menyebabkan bacaan $\mathrm{pH}$ pada telaga tersebut menjadi lebih berasid. Kepekatan Fe ini boleh disebabkan kerana ia merupakan unsur yang keempat banyak terkumpul dalam kerak bumi (Alhibshi et al. 2014). Bagi sampel NSTPW 23 pula, unsur Pb adalah melebihi nilai yang telah ditetapkan. Secara keseluruhannya didapati bahawa air bawah tanah di sekitar Tampin adalah merupakan sebahagian daripada akuifer yang terletak di atas batuan dasar dengan batuan dasar ini mengandungi mineral yang mempunyai kepekatan unsur logam berat tertentu.

\section{KESIMPULAN}

Berdasarkan kepada kajian ini, didapati bahawa terdapat beberapa faktor semula jadi yang mempengaruhi kualiti air bawah tanah ini. Berdasarkan kepada analisis yang telah dijalankan, didapati bahawa air bawah tanah di kawasan kajian ini boleh dikategorikan sebagai air mentah/air semula jadi yang tidak tercemar berdasarkan kepada nilai TDS yang paling tinggi iaitu $658 \mathrm{mg} / \mathrm{L}$ dengan nilai ini adalah di bawah $1000 \mathrm{mg} / \mathrm{L}$ bagi air semula jadi. Suhunya pula adalah pada sekitar $31.8^{\circ} \mathrm{C}$. Namun begitu, peningkatan suhu ini boleh menyebabkan perluluhawaan batuan dan akan mewujudkan larutan kimia kepada sumber air bawah tanah ini.

Analisis hidrogeokimia yang menggunakan Gambarajah Piper pula menunjukkan bahawa air bawah tanah didominasi oleh jenis $\mathrm{Ca}^{2+} \mathrm{HO}_{3}^{-}$, diikuti oleh $\mathrm{Na}^{+}$ $\mathrm{HO}_{3}^{-}$, dan $\mathrm{Ca}^{-} \mathrm{Na}^{-} \mathrm{HO}_{3}^{-}$. Gambarajah Gibbs pula telah menunjukkan bahawa evolusi hidrokimia air bawah tanah adalah dominan kepada interaksi antara air tanah dan batuan serta air hujan. Sebagai kesimpulan, air bawah tanah di daerah Tampin ini adalah selamat untuk digunakan. Namun begitu, langkah pengawalan perlu diambil bagi mengelakkan berlakunya pencemaran pada masa akan datang.

\section{PENGHARGaAN}

Penulis ingin mengucapkan jutaan terima kasih kepada Jabatan Mineral dan Geosains atas sokongan, data, dan bantuan teknikal yang disumbangkan untuk kajian ini. Penghargaan juga diberikan kepada Universiti Kebangsaan Malaysia atas bantuan kewangan yang disumbangkan melalui geran penyelidikan GUP-2017-083.

\section{RUJUKAN}

Alhibshi, E., Albriky, K. \& Bushita, A. 2014. Concentration of heavy metals in underground water wells in Gharian district, Libya. International Conference on Agricultural, Ecological and Medical Sciences (AEMS-2014), February 6-7.

Annapoorna, H. \& Janardhana, M.R. 2015. Assessment of groundwater quality for drinking purpose in rural areas surrounding a defunct copper mine. Aquatic Procedia 4: 685-692.

Balachandar, D., Sundararaj, P., Rudhravel, K. \& Kumaraswamy, K. 2010. An investigation of groundwater quality and its suitability to irrigated agriculture in Coimbatore District, Tamil Nadu, India - A GIS Approach. International Journal of Environmental Sciences 1(2): 176-190.

Batayneh, A. \& Zumlot, T. 2012. Multivariate statistical approach to geochemical methods in water quality factor identification: Application to the shallow aquifer system of the Yarmouk Basin of North Jordan. Research Journal of Environmental and Earth Sciences 4(7): 756-768.

BERNAMA. 2018. Cuaca panas: Paras air empangan dipantau.

Chapman, D. 1992. Water Quality Assessment: A Guide to Use of Biota, Sediments and Water in Environmental Monitoring. London: Chapman and Hall Ltd.

Davis, S.N. \& De Wiest. 1996. Hydrogeology. New York: John Wiley \& Sons. p. 463.

Gibbs, R.J. 1970. Mechanisms controlling world's water chemistry. Science, New Series 170(3962): 1088-1090.

Hakim, M.A., Juraimi, A.S., Begum, M., Hasanuzzaman, M., Uddin, M.K. \& Islam, M.M. 2009. Suitability evaluation of groundwater for irrigation, drinking and industrial purposes. American Journal of Environmental Sciences 5(3): 413-419

Hamzah, Z., Rosdi, W.N.W., Wood, A.K.H. \& Saat, A. 2014 Penentuan kepekatan ion-ion utama air telaga di Kelantan, dengan menggunakan pendaflur serakan tenaga sinar- $X$ dan ion kromatografi. Malaysian Journal of Analytical Sciences 18(1): 178-184.

Hem, D. 1985. Study and Interpretation of the Chemical of Natural Characteristics of Natural Water. U.S. Geological Survey, Water Supply Paper 2254.

Hosseini, N., Johnston, J. \& Lindenschmidt, K.E. 2017. Impacts of climate change on the water quality of a regulated prairie river. Water (Switzerland) 9(3): 1-15.

Hwang, J.Y., Park, S., Kim, H.K., Kim, M.S., Jo, H.J., Kim, J.I., Lee, G.M., Shin, I.K. \& Kim, T.S. 2016. Hydrochemistry for the assessment of groundwater quality in Korea. Journal of Agricultural Chemistry and Environment 6(1): $1-29$.

Kementerian Kesihatan Malaysia (KKM). 2004. Manual Kawalan Mutu Air Minuman. Jilid 1.

Kumar, S., Logeshkumaran, A., Magesh, N.S., Godson, P.S. \& Chandrasekar, N. 2014. Hydro-geochemistry and application of water quality index (WQI) for groundwater quality assessment, Anna Nagar, part of Chennai City, Tamil Nadu, India. Applied Water Science 5(4): 335-343.

Liang, Z., Chen, J., Jiang, T., Li, K., Gao, L., Wang, Z. \& Xie, Z. 2018. Identification of the dominant hydrogeochemical processes and characterization of potential contaminants in groundwater in Qingyuan, China, by multivariate statistical analysis. RSC Advances 8(58): 33243-33255.

Niaz Ahmad, Zekai Şen. \& Manzoor Ahmad. 2003. Ground water quality assessment using multi-rectangular diagrams. Ground Water 41(6): 828-832. 
Piper, A.M. 1944. A graphic procedure in the geochemical interpretation of water-analyses. EOS, Transactions American Geophysical Union 25: 914-928.

Sapari, N., Azie, R.Z.R. \& Jusoh, H. 2011. Quantity and quality of groundwater in fractured metasedimentary rocks of the West Coast of Peninsular Malaysia. Sains Malaysiana 40(6): 537-542.

Seribu, K. \& Jakarta, D.K.I. 2017. Analisis karakteristik hidrogeokimia airtanah di Pulau Koral Panggal. Jurnal Geografi 9(2): 99-108.

Shankar, K., Aravindan, S. \& Rajendran, S. 2017. Hydrochemical profile for assessing the groundwater quality of Paravanar River sub-basin, Cuddalore District, Tamil Nadu, India. Current World Environment 1(1): 4552.

Shirazi, S.M., Adham, M.I., Zardari, N.H., Ismail, Z., Imran, H.M.D. \& Mangrio, M.A. 2015. Groundwater quality and hydrogeological characteristics of Malacca state in Malaysia. Journal of Water and Land Development 24(13): 11-19.

Subyani, A.M. \& Ahmadi, M.E.A. 2010. Multivariate statistical analysis of groundwater quality in Wadi Ranyah, Saudi Arabia. Journal of King Abdulaziz University, Earth Sciences 21(2): 29-46.

Shivashankara, G.P., Sharmila, G.V. \& Shruthi, R. 2016 Interaction of precipitation and groundwater chemistryKarnataka, India. International Journal of Environmental Science and Development 7(8): 568-575.

SPAN. 2014. Laporan Tahunan Suruhanjaya Perkhidmatan Air Negara.

Umar Kura, N., Firuz Ramli, M., Azmin Sulaiman, W.N., Ibrahim, S., Zaharin Aris, A. \& Mustapha, A. 2013. Evaluation of factors influencing the groundwater chemistry in a small tropical Island of Malaysia. International Journal of Environmental Research and Public Health 10(5): 18611881.
Tanuguchi, M. \& Holman, I.P. 2010. Groundwater Response to Changing Climate. Boca Raton: CRC Press.

Unit Perancang Ekonomi Negeri. 2015. Data Sosioekonomi Negeri Sembilan.

Utusan Malaysia. 2016. Paras air di Empangan Gemencheh di bawah paras kritikal. http://www.utusan.com.my/berita/ national/patas-air-di-empangan-gemencheh-di-bawahparas-kritikal-1.184683, diakses pada 11 November 2017.

WHO. 1996. Total dissolved solids in drinking-water. In Guidelines for Drinking-Water Quality. 2nd ed. Volume 2. World Health Organization Geneva.

Norhayati Mohd Rawi, Nursabrina Syahirah Hairudin, Norbert Simon* \& Norsyafina Roslan

Pusat Sains Bumi dan Alam Sekitar

Universiti Kebangsaan Malaysia

43600 UKM Bangi, Selangor Darul Ehsan

Malaysia

Lee Khai Ern \& Norbert Simon*

Institut Alam Sekitar dan Pembangunan

Universiti Kebangsaan Malaysia

43600 UKM Bangi, Selangor Darul Ehsan

Malaysia

Norbert Simon*

Pusat Kajian Bencana Alam (NDRC)

Universiti Malaysia Sabah

88400 Kota Kinabalu, Sabah

Malaysia

*Pengarang untuk surat-menyurat; email: norbsn@ukm.edu.my

Diserahkan: 25 Jun 2019

Diterima: 5 Disember 2019 